\title{
The phenomenon of moscatel sparkling wine in Brazil
}

\author{
M.V. Araujo ${ }^{a}$, M.A.C. da Silva, and K.L. Bruch \\ Centre of Studies and Researches in Agribusiness - Universidade Federal do Rio Grande do Sul, Av. Bento Gonçalves, 7712 Porto \\ Alegre, RS Brazil
}

\begin{abstract}
This article sought bases and contexts of social representation of sparkling wine muscatel in Brazil. It is a base for more complex studies. A phenomenon of increased sparkling wine consumption in Brazil was perceived, mainly from muscatel sparkling wine, which increased by $417 \%$ from 2005 to 2017. Sparkling wine is a product that appeared in France and migrated to other countries after colonization. In Brazil, it has been gaining more and more visibility, be it in music, news, supermarkets, and other social contexts. To understand this phenomenon, we sought the media and cultural databases, i.e. music, online newspapers. In Brazilian music, the sparkling wine is represented as a luxury product, which refers to romance, festivities, celebrations, special moments, seduction, special gifts, social differentiation, among others. In others media, it is perceived as a fresh, light drink, with pleasant sweetness and easiness to drink, and also an option for those who want to start venturing into the world of wine. As an exploratory and developing research, it was possible to lay down a foundation for further investigation about the social representation of sparkling wine in Brazil.
\end{abstract}

\section{Introduction}

Studying wine culture means to go a long way from the craftwork production of wine to its modern processes of elaboration. Such culture was brought by European colonizers' families to Brazil, mainly through Catholic rituals [1]. The countries of the Old World exported the wine culture to the regions which came to be known as the New World and the "New New World", which use different techniques and have developed different habits. The Old World is represented mainly by the countries of Western and Southern Europe, with old and traditional techniques. The New World is made up of countries colonized by the Old World, such as the United States, Chile, Australia, South Africa, New Zealand, Argentina and Brazil, which are characterized as innovative and nonconservative regions [2]. The "New New World" are some regions that have begun to produce and consume wine quite recently, like some Brazilian regions.

Within this concept, new frontiers of production and consumption have been established. In Brazil the forms of production and consumption are distinguished from Europe and some of the New World countries. Banks and Overton (2010) present some features of developing countries, which produced only for local markets (local elites), and, after adopting new and more modern technologies, have now reoriented to quality and export markets. The authors show that new forms of consumption in these countries also pressure production. With the growth of the middle class, the wine market developed rapidly, investments have risen and people migrated between regions and companies. New wine styles are emerging for new consumers.

\footnotetext{
a e-mail: araujovmarcos@gmail.com
}

There are still few studies dedicated to understanding wine consumption in Brazil. However, the sector (IBRAVIN) reports a steady growth in sales (Table 1). The Brazilian sparkling wine received special attention, since it has been having greater domestic demand in the last few years than its imported competitors. According to Euromonitor (2017), this trend is due to higher prices of the imported products, even if they are still occasionally consumed. This trend represents a change regarding what had been happening before: Brazilians are increasingly consuming national sparkling wines, mainly for their costbenefit ratio. The demand has increased rapidly, even though Brazilians tend to prefer imported products [4].

However, regarding the formation of taste, one must question what sparkling wine represents in the social relations of its consumers. Products that once represented a distinction between classes, now, in a new context, represent a genuine consumer preference [5]. However, in order to investigate the influence of sparkling wine on social relations, it is important to think about the relationships themselves, based on contexts, influences of images and status.

To understand the representation of sparkling wine, it is necessary go beyond the representation of the individual and his relation with the object (sparkling wine). One must understand the collective representation, which makes an individual belong to a certain society or group [6]. Thus, considering the sparkling wine as a more elitist product, we propose to understand how this representation was constructed over time. This proposition is based on the fact that wine is a distinct drink, a symbol of maturity, which projects different images and representations in society [7].

Thus, the purpose of this article is to seek some bases and contexts of social representations of sparkling 
Table 1. Evolution of wine commercialization in Brazil.

\begin{tabular}{lllllllll}
\hline Year & $\mathbf{2 0 1 0}$ & $\mathbf{2 0 1 1}$ & $\mathbf{2 0 1 2}$ & $\mathbf{2 0 1 3}$ & $\mathbf{2 0 1 4}$ & $\mathbf{2 0 1 5}$ & $\mathbf{2 0 1 6}$ & $\mathbf{2 0 1 7}$ \\
\hline Table wine* & 215.05 & 230.05 & 205.48 & 212.51 & 206.00 & 207.61 & 165.94 & 173.70 \\
\hline Fine wine (nat)** & 18.37 & 19.54 & 18.76 & 20.11 & 19.28 & 19.78 & 19.22 & 15.58 \\
\hline Sparkling wine (nat)** & 12.58 & 13.16 & 14.74 & 15.91 & 16.79 & 18.79 & 16.85 & 17.40 \\
\hline Fine wine (imp) & 71.01 & 72.71 & 74.22 & 67.95 & 76.91 & 77.69 & 88.39 & 118.80 \\
\hline Sparkling wine (imp) & 4.31 & 4.92 & 5.32 & 4.27 & 4.32 & 4.11 & 3.75 & 7.07 \\
\hline Total *** $^{* *}$ & $\mathbf{3 2 1 . 3 2}$ & $\mathbf{3 4 0 . 3 8}$ & $\mathbf{3 1 8 . 5 2}$ & $\mathbf{3 2 0 . 7 5}$ & $\mathbf{3 2 3 . 3 0}$ & $\mathbf{3 2 7 . 9 9}$ & $\mathbf{2 9 4 . 1 5}$ & $\mathbf{3 3 2 . 5 8}$ \\
\hline
\end{tabular}

*From american grapes and hybrids (vitis labrusca and vitis sp.); **Data of Brazilians wine market is only from Rio Grande do Sul State that represent $90 \%$ of Brazilian wine production; $* * *$ millions liters. (nat-national; imp-imported)

Source: IBRAVIN-SISDECLARA, adapted by authors.

muscatel in Brazil, as well as to be a foundation for more complex studies.

\subsection{The emergency of sparkling wine}

Sparkling wine appears in history as a mistake, due to the second natural fermentation that happens inside a bottle (or barrel), which produces carbon dioxide. The sparkling wine is characterized as an extravagant variety of wine, precisely because it is sparkling. It first appears as an expensive product due to production difficulties and its establishment among the French aristocracy, even though it did not come from the Champagne region [8]. The process of double fermentation, bottling and even the success of sparkling wine came first to England, with products from France (Champagne) in 1700s. The United Kingdom is still the largest Champagne market [9].

New territories were occupied and dominated in the process of land appropriation around the world by the European man, still seen as Europeanization. Homogeneous images and representations between various regions of the world, without excluding individual particularities, have begun to flow [10]. The wine, as a cultural object, followed these flows of globalization, from colonization to more recent movements, such as decolonization and increased sharing of communication and information.

In Brazil, the wine cycle has also begun with colonization. The first wines and vines arrived there by the hands of the Portuguese, following the prohibition of manufacturing industries, until the arrival of Italians and Germans. This changed the profile of the production to American strains; later, with the wine sector modernization, wines began to be elaborated from Vitis Viniferas grapes (fine wine). During this period, wine production gained more national and international visibility (see [1]). Winemaking then arrived at its modern stage in Brazil at the beginning of the 20th century, which also coincides with the beginning of sparkling wine elaboration [1].

Over time, the culture of wine production and consumption has spread to other regions of Brazil. New wineries emerged, and later national products gained visibility, winning prizes and competing over imported ones. These products came to meet the national demand for price and quality, which can be observed by the increase in the domestic market for sparkling wines (Table 1).

The data provided by the wine sector (SISDECLARAIBRAVIN) corroborates this change. Sparkling wine is highlighted by an increase in sales in recent years. The consumption of sparkling wine in Brazil increased more than $160 \%$, especially of muscatel, with an increase of $417 \%$ between 2005 and 2017. However, in terms of

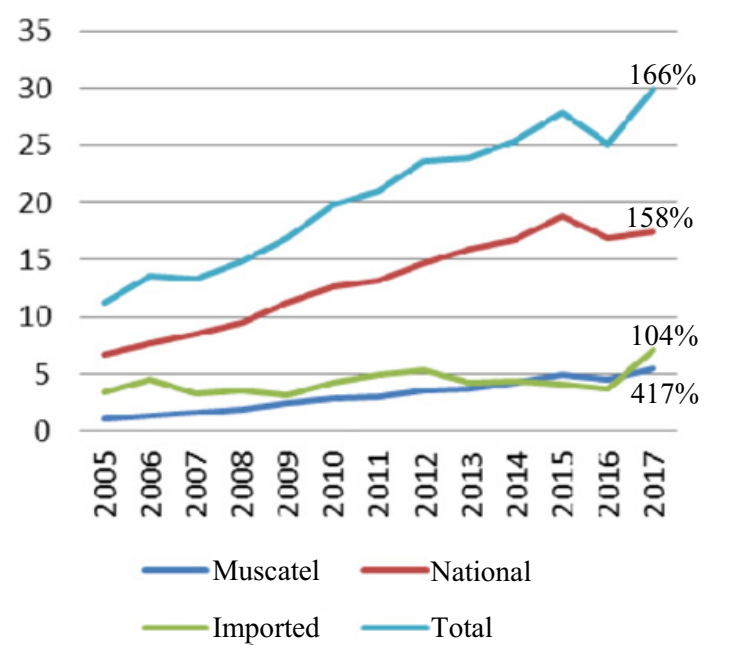

Figure 1. Evolution of sparkling wine commercialization in Brazil. Source: authors, adapted from IBRAVIN-SISDECLARA.

volume it is still insignificant. On the other hand, the consumption of imported sparkling wine increased only $104 \%$, while national sparkling wine, both conventional and muscatel, rose $158 \%$ in the same period (Fig. 1).

In parallel with the increase in wine consumption after World War II, Brazil experienced an increase in inequality. However, since 1990, inequality has decreased due to the increase in per capita income [11]. This phenomenon follows the increase of the Brazilian middle class, which resulted in an increase of sparkling wine consumption.

These changes in drinking habits are also perceived in other countries, but with different intensity. In Europe, the case of beer and wine is seen as a cultural convergence. This is also the case in Latin America, although at a slower pace, which may be related to the delay in market opening [12]. In the case of Brazil, the increase in income suggests a change in demand for better quality wines [13], which is also evident in relation to the increase of sparkling wine consumption.

A different phenomenon occurs in UK: among the leading countries in imported Champagne, recently sparkling Prosecco has been gaining more ground. One of possible reasons is its image as a cheaper alternative to Champagne, "a day-to-day luxury" [14].

Nonetheless, this is a global phenomenon. The International Organization of Wine and Vine (OIV) indicates growth in volume and value of effervescent wines, a category that includes sparkling wine. On the other hand, after a period of decline, there is a stagnation in wine consumption in European countries, 
traditional producers and consumers of wine [15]. Given the fluctuation in sparkling wine consumption, what does this phenomenon represent regarding habits change and what could mean to Brazilians?

Cultural and social practices, like consumer behavior, are related and evidenced by their representations [16]. Representations, in turn, are beliefs built and maintained socially, shared by individuals in a particular social group [17]. They are made up of available information and knowledge shared by groups. The attribution of these representations to the object is influenced by social context, which contributes to social construction of reality, in which an individual seeks to satisfy his social point of view, group identity and sense of social differentiation [18].

The way people identify and project their image and interact with others varies according to the culture where they are inserted and their formation of palate [19]. Therefore, it depends on the origin and the level of knowledge of a group. Thus, the objective of this research is to understand the phenomenon of sparkling wine in Brazil, focusing on muscatel. Evidences were sought in cultural products, common sense content and media, to understand the emergence of consumption and the acceptance of this product.

\section{Method}

This research is based on thematic analysis in media and cultural content over time, in order to obtain evidence that could explain the increase of sparkling wine consumption in Brazil. It aims to seek the content shared between groups and for the groups, in order to analyze its origin and how sparkling wine muscatel became a product shared strongly among Brazilian consumers.

Content selection occurred randomly. From searches on internet, news, music and media that express representations about sparkling wine. The selection method chosen was due to lack of more precise information about the subject. A simple content analysis was performed, focused on expression of meaning of traditional sparkling wine as well as sparkling wine muscatel.

\section{Results}

\subsection{The sparkling wine in Brazil}

The largest wine producer state in Brazil, Rio Grande do Sul, is also the largest producer of sparkling wine. This state sells half of its yearly sparkling wine production between Christmas and New Year [20]. However, this habit has been transferred from these festivities to a more general consumption throughout the year [21].

In Brazil, the production of sparkling wine began in 1913, by Manoel Peterlongo. The production was increased with the arrival of multinational companies in the 60's [21]. Over the years, sparkling wine has gained visibility and varied forms of production. According to Brazilian law, there are two types of sparkling wines, sparkling wine (vinho espumante, in Portuguese), "champagne" or natural sparkling wine, and the sparkling wine muscatel. The difference is mainly due to the method of elaboration. As for the former, carbon dioxide comes

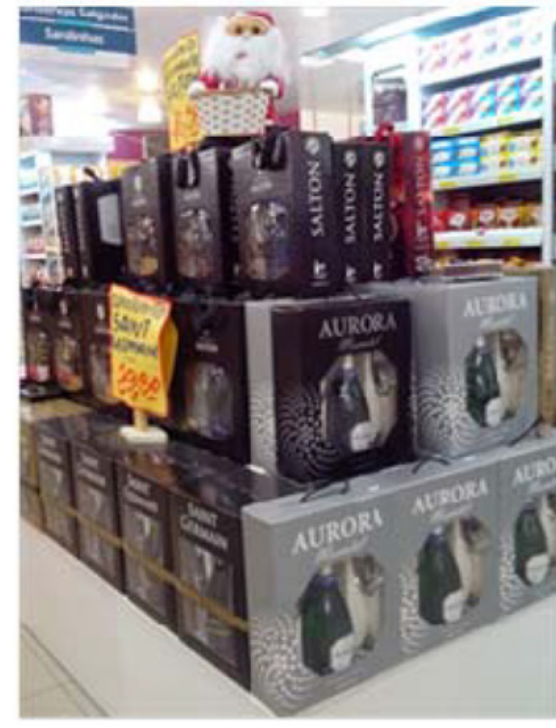

Figure 2. Supermarket shelf in Brazil. Source: [47].

from the second fermentation, as for the latter, carbon dioxide comes from the first fermentation [22]. It is important to highlight that carbonated, gasified wine, semisparkling, sweet filtered, cider, fermented fruit, mixed alcoholic beverages and soft drinks are not considered sparkling wines, however, "bubbly" or gasified drinks [23].

As shown in Fig. 1, in Brazil, there was an increase in the presence of sparkling wine as among common Brazilian beverages. This presence extrapolates numbers, but also appears in music, media, as well as in supermarket shelves and parties (Fig. 2). It is important to emphasize the importance of sparkling wine muscatel, which emerged around 15 years ago and has great appreciation among Brazilian consumers [24].

Likewise, in Brazilian music the sparkling wine is represented as a luxury product, which is related to romance, festivities, celebrations, special moments, seduction, special gifts, social differentiation, among others.

Sparkling wines are in luxury categories and, like champagne, "tend to use historical ceremonies and traditions to establish their value" [25, P.3]. This symbolism associated with sparkling wine is seen daily through social networks and the disposition of these products in supermarkets. When they substitute other drinks in special shelves at the end of the year, sparkling wine, especially muscatel, represents a new cultural arrangement in different groups. In some parties, sparkling wine is placed as an object of exposure, with fireworks, publications in social networks, demonstrating the luxury of consuming this product, which can also be perceived in some Brazilian songs.

Musical expressions can express much of what sparkling wine represents for Brazilian society. Music reflects the social context in which sparkling wines are produced and consumed. Whether in the present or in the past, it brings with it indicators and cultural elements, as well as reflections of Brazilian values and way of life [26]. Popular music, as a space for interaction and communication, can be a source of identification of social representations [27], it brings much of popular thought and, from what is sung [28]. As a product present in 
daily life of celebrations, sparkling wine, sparkling, or champagne (vinho espumante, espumante or champanhe, in Portuguese), as it is commonly called in Brazil, is present in several musical styles and lyrics.

In Brazilian funk, rap, pagode, samba, sertanejo, popular songs in Brazil, sparkling wine represents money, fame, ostentation and luxury as in music of Tribo da Periferia (RAP) and MC Keety (Brazilian funk) Charlie Brown Jr. [29-31]. Also represents alcohol consumption, but often associated with drinks that refer to the person's social status, such as MC Jheffinho (funk) [32], in addition to special moments that are offered or accompanied by sparkling wine or special gift, as in lyrics of César Menotti and Fabiano (sertanejo), Ludmilla (Dance/Pop) Cazuza (Rock), Roberta Miranda (sertanejo) [33-36], or even more emblematic songs that use sparkling wine as its motif, often of the French brand Chandon, as something just visual and not to be consumed, such as Tony (pagode), Rodrigo Reys (sertanejo) and the Band Luxuria [37-39], which says "Champagne was not made to drink, champagne was made to bathe", and in their concerts use to squirt sparkling wine on the audience (funk/brega). There are different groups and represent different publics, each approaching the sparkling wine differently.

This may show the relationship of Brazilians with sparkling wine consumption and possible representations in different groups. Be it elegance, a toast, luxury, ostentation, demonstration of power and income. But it still does not highlight the type of product consumed, preferences and real social representation categorized by groups or targets.

On the other hand, there are several representations separating traditional sparkling wine and muscatel, but at the same time converging. Sparkling wine muscatel in recent years has been gaining space in the end-of-year shelves and greater commercialization in Brazil. Muscatel is seen as a product that fits the demands of Brazilians. It is seen as "light, fresh, with pleasant sweetness and easy to drink. Sparkling wine muscatel is very well known among Brazilians and also an excellent option for those who want to start venturing into the world of wine" [40].

Likewise, its organoleptic characteristics are highlighted. Muscatel is seen as a product beyond traditional ones, which also represents sparkling wine, with an incomparable sweetness and a fruity and floral aroma [41]. It is the gateway to the world of sparkling wines, with a good cost-benefit ratio, well awarded internationally and indicated for summer as well as for winter time [42]. It is a versatile product that adapts to various occasions [43]. A cheerful sparkling wine, uncompromising and that cannot be compared to other sparkling wines. Besides, it is relatively cheap [44]. Muscatels are recognized by prizes received in international competitions and by its affordable price to consumer [45]. A typical product of Brazilian winemaking and aromatic intensity [24]. Finally, it is a product remembered for the international awards, the positive criticism of specialists and the ease of drinking it, which brings in news "the rise of Muscatel" [46].

The news shows the connection between Brazilian consumers' preferences and the possible adaptation to consume sparkling muscatel. A product that is not only present in young parties, but which is beginning to make part of Brazilians habits for its ease of access (taste and price).

\section{Discussion}

This research aimed to bring an initial understanding about the emergence of Brazilian sparkling wine as a social phenomenon. In order to do this, evidence was collected in media and cultural content (I.e. music, news and industry data). The notoriety of Brazilian sparkling wine is perceptible in relation to other national and international wine products. Its significant increase in internal marketing is evidence of its strength in the wine sector. Moreover, news and awards also express this strength, which proves the product's quality.

Thus, sparkling wine continues to have formerly shared representations such as elegance, luxury, celebrations and gifts. However, in Brazil, it comes to represent a possible class membership, when it is brought as something of social differentiation in music and party photos, in balconies and nightclubs. Furthermore, muscatel has become a versatile beverage, mainly when compared to traditional sparkling wine. In news, sparkling wine muscatel is seen as a light, fresh and sweet product. Taking as reference the sweet palate of Brazilians, this evidence shows the reasons of its acceptance before the Brazilian public.

Therefore, the awards, flavor and gain in product quality, in addition to the increase in per capita income of Brazilians, confirm the existence of a sparkling wine muscatel phenomenon. Its greater presence in shelves, parties and toasts accompanied by fireworks, shows its importance as a symbol of belonging and social status.

However, this is an exploratory and developing research, which serves as a basis for further research about social representations of sparkling wine. This study still requires deeper research with consumers, in addition to other data. Despite this, it already presents clues about sparkling wine muscatel as a phenomenon in the Brazilian wine sector. It also points the way for new research, as well as the importance of studies on sparkling wine, especially regarding cross-referencing of data between new and traditional consumers.

This research was financed with a $\mathrm{PhD}$ scholarship by the Coordination for the Improvement of Higher Education Personnel - Capes (PDSE-CAPES 47/2017) in Brazil.

\section{References}

[1] V.C. Ferreira e M. de M. Ferreira, Vinhos do Brasil - Do passado para o futuro (Rio de Janeiro, FGV Editora, 2016)

[2] G. Banks e J. Overton, J. Wine Res. 21, 57 (2010)

[3] Euromonitor, "Wine in Brazil", COUNTRY REPORT, 2017. [Online], Available at: http:// www.portal.euromonitor.com/portal/analysis/ tab [accessed: 11-Jan 2018]

[4] M.-C. Veillette, Glob. Wine Spirits Mark. Reports, 16 (2013)

[5] Z. Bauman, A cultura no mundo liquido moderno (Rio de Janeiro, Zahar, 2013)

[6] S. Delouvée, "La théorie des représentations sociales?: quelques repères socio-historiques", in Les représentations sociales - Théories, méthodes et applications (Ouvertures., Gregory Lo Monaco, 
Sylvain Delouvée, e Patrick Rateau, Orgs. Louvainla-neuve: Deboeck Supérieur, 2016), pp. 39-50

[7] C. Simonnet-Toussaint, A. Lecigne, e P.-H. Keller, Bull. Psychol. 479, 535 (2005)

[8] B. Musset, "Le Champagne ou l'élaboration $\mathrm{du}$ premier vin mousseux dans un territoire.", Les origines de l'effervescence, 2009. [Online]. Available at: https://www. champagne.fr/fr/ terroir-appellation/histoire-du-vignoblechampenois-et-appellation-champagne/ origines-effervescence. [accessed: 14-maio2018]

[9] M. Lecrosnier-Wittkowsky, Les Grappes, (2015)

[10] P.M. Defarges, La Mondialisation, $3^{\circ}$ ed. (Paris: PUF, 1997)

[11] J.P. Wogart, Brazilian J. Polit. Econ. 30, 381 (2010)

[12] J. Aizenman e E. Brooks, Rev. Int. Econ. 16, 217 (2008)

[13] A.N. Almeida, C. Bragagnolo, e A.L.S. Chagas, Rev. Econ. e Sociol. Rural 53, 433 (2015)

[14] O. Blair, "Prosecco: how the italian sparkling wine knocked champagne off its pedestal", INDY/LIFE, 2017. [Online]. Available at: https : // www. independent.co.uk/life-style/foodand-drink/prosecco-italian-sparklingwine-how-beat-champagne-france-a7751971 . html. [accessed: 20-maio-2018]

[15] OIV, "Elements de Conjoncture Mondiale", Paris, 2017

[16] M. Mouret, G. Lo Monaco, I. Urdapilleta, e W.V. Parr, Food Qual. Prefer. 30, 102 (2013)

[17] G. Lo Monaco, F. Lheureux, e S. Halimi-Falkowicz, Swiss J. Psychol. 67, 119 (2008)

[18] G. Lo Monaco, L. Gaussot, e C. Guimelli, Prat. Psychol. 15, 473 (2009)

[19] H. Rodrigues, J. Ballester, M.P. Saenz-Navajas, e D. Valentin, Food Qual. Prefer. 46, 166 (2015)

[20] G1 RS, "Rio Grande do Sul produz mais de 90\% dos espumantes do Brasil", Rio Grande do Sul, 2017. [Online]. Available at: https://g1. globo.com/rs/rio-grande-do-sul/campo-elavoura/noticia/rio-grande-do-sul-produzmais-de-90-dos-espumantes-do-brasil.ghtml. [accessed: 01-ago-2018]

[21] D. Wurz, "Espumantes: Um pouco de História!", Falando em Vinhos, 2015. [Online]. Available at: https://falandoemvinhos.wordpress . com/ 2015/05/17/espumantes-um-pouco-de-historia/. [accessed: 01-ago-2018]

[22] BRASIL, "Lei no 7.678, de 8 de novembro de 1988", 2014. [Online]. Available at: http://www. planalto.gov.br/ccivil_03/leis/1980-1988/ L7678.htm. [accessed: 02-ago-2018]

[23] K.L. Bruch, "Nem tudo que borbulha é espumante", Bento Gonçalves, 2012

[24] A. Hoffmann, "Sistema de Produção de Vinho Moscatel Espumante", Bento Gonçalves, 2008

[25] K. Cowan e N. Spielmann, J. Brand Manag. 24, 391 (2017)

[26] M.W. Bauer, "Analyzing Noise and Music as Social Data", in Qualitative Researching with Text, Image and Sound: A Practical Handbook for Social
Research, edited by M.W. Bauer e G. Gaskell (Orgs. London: Sage Publishing, 2000), pp. 263-281

[27] A. Roberto, A. Nascimento, L.C. Queiroga, e L. Celia, Psicol. Soc. 27, 231 (2015)

[28] S.M. dos S. Coutinho, Z.A. Trindade, M.C.S. Menandro, e P.R.M. Menandro, Estud. Psicol. 32, 461 (2015)

[29] Tribo da Periferia, "Champagne Chandon", 2013. [Online]. Available at: https://www.letras. mus.br/tribo-da-periferia/1759682/ [accessed: 10-jun-2018]

[30] M.C. Keety, "Whisky \& Chandon", 2014. [Online]. Available at: https://www.letras . mus.br/mc-keety/whisky-e-chandon/ [accessed: 10-jun-2018]

[31] C. Brown Jr, "Champanhe e Água Benta", 2008. [Online]. Available at: https://www. letras. mus.br/charlie-brown-jr/76615/ [accessed: 10-jun-2018]

[32] KondZilla, "MC Jheffinho - His, Chandon, Whisky", 2014. [Online]. Available at: https://www . youtube. $\mathrm{com} /$ watch? $\mathrm{v}=3 \mathrm{Id}-\mathrm{fkTvfYE}$ [accessed: 10-jun-2018]

[33] C. Menotti e Fabiano, “Chandon”, 2016. [Online]. Available at: https://www.letras. mus.br/cesar-menotti-e-fabiano/chandon/ [Acessado: 10-jun-2018]

[34] Ludmilla, "Bom", 2016. [Online]. Available at: https://m.letras.mus.br/ludmilla/bom/ [accessed: 10-jun-2018]

[35] Cazuza, “Champanhe e Gentileza”, 1990

[36] R. Miranda, "Champagne", 1986. [Online]. Available at: https://www.vagalume.com.br/ roberta-miranda/champagne.html [accessed: 10-jun-2018]

[37] Tony, "Chuva de Chandon", 2013. [Online]. Available at: https://www.letras.mus.br/ tony/chuva-de-chandon/ [accessed: 10-jun2018]

[38] R. Reys, "Banho de Chandon", 2013. [Online]. Available at: https://www.letras. mus.br/rodrigo-reys/banho-de-chandon/ [accessed: 10-jun-2018]

[39] B. Luxúria, "Banho de Champagne", 2013. [Online]. Available at: https://www.letras. mus.br/banda-luxuria/banho-de-champagne/ [accessed: 10-jun-2018]

[40] N. Batista, "O espumante moscatel", Winepedia, 2017. [Online]. Available at: https://winepedia. com.br/sommelier-wine/espumante-moscatel/ [accessed: 23-jul-2018]

[41] J. Marini, "Conheça o espumante Moscatel e sua doçura incomparável!", Famiglia Valduga CO, 2017. [Online]. Available at: http://blog. famigliavalduga.com.br/conheca-oespumante-moscatel-e-sua-docuraincomparavel/ [accessed: 04-ago-2018]

[42] J.F. Clemente, "Desafio de Espumantes Moscatel - Resultados", Falando de vinhos, 2009. [Online]. Available at: http://www . falandodevinhos.com/2009/11/16/desafiode-espumantes-moscatel-2/ [accessed: 04-ago2018] 
[43] IBRAVIN, "Dicas práticas para beber espumantes", Destemperados, 2016. [Online]. Available at: https://destemperados.clicrbs.com.br/ bebidas/dicas-praticas-para-beberespumantes?ccattr $=10081822$ [accessed: 04-ago-2018]

[44] S. Galvão, "Familia Moscatel", Estadão, 2009. [Online]. Available at: https://www.estadao. com.br/noticias/geral, familia-moscatel,2765. [accessed: 04-ago-2018]
[45] UOL, "Espumante brasileiro de $\mathrm{R} \$ 43.50$ é escolhido o $5^{\circ}$ melhor vinho do mundo", UOL, 2017. [Online]. Available at: https:// economia.uol.com.br/noticias/redacao/ 2017/09/28/premio-vinhos-brasileiros.htm [accessed: 05-ago-2018]

[46] C. Masson, “A ascensão do moscatel", ISTOÉ, 2017. [Online]. Available at: https://istoe. com.br/ascensao-do-moscatel/ [accessed: 05ago-2018] 